\title{
Leafy Spurge Suppression by Flea Beetles in the Little Missouri Drainage Basin, USA
}

\author{
Luke W. Samuel, ${ }^{1}$ Donald R. Kirby, ${ }^{2}$ Jack E. Norland, ${ }^{1}$ and Gerald L. Anderson ${ }^{3}$ \\ Authors are ${ }^{1}$ Research Specialists and ${ }^{2}$ Professor, Animal and Range Sciences Department, North Dakota State University, Fargo, ND 58105, USA; and \\ ${ }^{3}$ Ecologist, USDA, Agricultural Research Service, Northern Plains Agricultural Research Laboratory, Sidney, MT 59270, USA.
}

\begin{abstract}
The Ecological Area-wide Management Leafy Spurge, or TEAM Leafy Spurge, began collecting and redistributing flea beetles (Aphthona spp.) to research/demonstration sites and landowners throughout the Little Missouri River drainage basin to control leafy spurge in 1998. A study to evaluate the change over time of leafy spurge (Euphorbia esula L.) phytosociological characteristics following release of flea beetles was initiated in 2002 on leafy spurge-infested pasture and rangeland in the Little Missouri River drainage of Montana, North Dakota, South Dakota, and Wyoming. A total of 292 flea beetle release sites were analyzed in June and July 2002 and 2003 for leafy spurge stem density, foliar cover, flea beetle density, and vegetation composition. Leafy spurge stem density suppression was evident at $91 \%$ of the study sites. On two-thirds of the study sites stem density was reduced from greater than 100 stems $\cdot \mathrm{m}^{-1}$ to less than $25 \mathrm{stems} \cdot \mathrm{m}^{-1}$. Leafy spurge foliar cover was less than $5 \%$ on approximately two-thirds of the flea beetle release sites and less than $25 \%$ on over $90 \%$ of the release sites. Area of observed leafy spurge suppression ranged from $0 \mathrm{~m}^{2}$ to $30000 \mathrm{~m}^{2}$. Approximately $40 \%$ of the release sites had leafy spurge suppression ranging from $1000 \mathrm{~m}^{2}$ to $5000 \mathrm{~m}^{2}$, and $14 \%$ of the release sites had greater than $10000 \mathrm{~m}^{2}$ of leafy spurge control. Plant community composition following leafy spurge suppression was characteristic of native plant communities that had not been burned or grazed. Flea beetles effectively reduced leafy spurge stem density and cover in 4-5 yr across a variety of locations and corresponding environmental conditions, both within the Little Missouri River drainage and in selected nearby locations.
\end{abstract}

\section{Resumen}

Para llevar a cabo el Manejo Ecológico de una amplia área de euphorbia fondosa se comenzó a recoger y a redistribuir escarabajos de pulga (Aphthona spp.) con la finalidad tanto de investigar y/o demostrarle a los propietarios localizados en sitios a lo largo de la cuenca del rio Little Missouri como controlar la euphorbia frondosa en 1998. Se llevo a cabo primero un estudio para evaluar el cambio de las características fitosociologías de la euphorbia (Euforbio esula L.) seguido después de la liberación de escarabajos de pulga en 2002 en un pastizal infestado de euphorbia en la cuenca del río Little Missouri en Montana, Dakota del Norte, Dakota del Sur y Wyoming. En un total de 292 sitios donde fueron liberados escarabajos de pulga fueron analizados en cuanto a la densidad de tallos de euphorbia, cubertura foliar, densidad de escarabajos de pulga y composición de la vegetación en Junio y Julio 2002 y 2003. La supresión de tallos de euphorbia fue evidente en el $91 \%$ de los sitios en estudio. En dos tercios de los sitios la densidad de tallos fue reducida de más de 100 tallos $\mathrm{m}^{2}$ a menos de 25 tallos $\mathrm{m}^{2}$. La cubierta foliar fue menos de $5 \%$ en aproximadamente dos tercios de los sitios de liberación de escarabajos de pulga y menos de $25 \%$ en $90 \%$ de los sitios de de liberación. El área de supresión de euphorbia frondosa fue $0 \mathrm{~m}^{2}$ a $30000 \mathrm{~m}^{2}$. Aproximadamente $40 \%$ de los sitios de liberación que tuvieron supresión de euphorbia frondosa se extendieron de $1000 \mathrm{~m}^{2}$ a $5000 \mathrm{~m}^{2}$ y el $14 \%$ de los sitios de liberación tuvieron mayor de $10000 \mathrm{~m}^{2}$ de control de euphorbia. La composición de la comunidad de plantas después de la supresión de la euphorbia fue característica de comunidades de plantas nativas que no habían sido quemadas o pastoreadas. Los escarabajos de la pulga redujeron con eficiencia la densidad y cubertura de tallos de euphorbia a través de una variedad de localidades y condiciones ambientales dentro de la cuenca del río Little Missouri y áreas adyacentes.

Key Words: Aphthona spp., biological control, introduced species, invasive weed, Little Missouri River drainage basin

\section{INTRODUCTION}

Leafy spurge (Euphorbia esula L.) is an exotic herbaceous, deep-rooted perennial noxious weed that infests over 2 million ha in 35 states and occurs in all the prairie provinces of Canada (Quimby and Wendel 1997). In North Dakota alone there are approximately 526000 ha of leafy spurge-infested lands (North Dakota Department of Agriculture 2001). Predominant areas of infestations are pastures, rangelands, roadsides, riparian areas, and waste places on a variety of soil types

Correspondence: Donald R. Kirby, North Dakota State University, 1301 12th Ave North, Fargo, ND 58701, USA. Email: donald.kirby@ndsu.edu

Manuscript received 26 September 2006; manuscript accepted 21 April 2008.
(Dunn 1979). Many infestations are found in environmentally sensitive areas such as river and stream banks, wooded areas, and lands having high water tables that prevent the use of some herbicides (Lym 1998). Bangsund and Leistritz (1991) estimated that leafy spurge infestations on rangelands cost the states of Montana, North Dakota, South Dakota, and Wyoming an estimated \$144 million annually (direct and indirect costs).

Traditional biological control uses imported natural enemies to suppress populations of a target exotic species to below economic or ecological levels (Dahlsten 1986; Quimby et al. 1991; Piper 2004). Leafy spurge has been identified as having the potential to be a good species for biological control efforts due to its low density in its native habitat and the abundance of host-specific insects associated with this species (Harris et al. 
1985; Gassmann and Schroeder 1995; Gassmann et al. 1996). Because of the size and scope of the leafy spurge problem in North America, Aphthona spp. biological control agents were introduced to control leafy spurge over $20 \mathrm{yr}$ ago (Anderson et al. 2003). Between 1998 and 2001 The Ecological Area-wide Management of Leafy Spurge, or TEAM Leafy Spurge (TLS), actively distributed black (Aphthona czwalineallacertosa Weiss and Rosenhauer) and brown (Aphthona nigriscutus Foundras) flea beetles to control leafy spurge in selected areas of North and South Dakota, Montana, and Wyoming (Anderson et al. 2003). Areas selected for flea beetle release represented a full array of edaphic, vegetation, and topographic variation in the region.

Flea beetle releases in the northern Great Plains have generally resulted in some level of leafy spurge suppression (Baker et al. 1996; Stromme et al. 1996; Kirby et al. 2000; Lym and Nelson 2000; Butler et al. 2006), although no suppression has also been observed (R. Lym, personal communication, October 2007). Limited data are available relating to plant community composition changes following leafy spurge suppression. The available reports suggest low species diversity, richness, and yield in plant communities following leafy spurge suppression (Kirby et al. 2000; Butler and Cogan 2004; Butler et al. 2006). Butler et al. (2006) noted an increase in graminoid cover on flea beetle release sites but no concomitant recovery in forb species density and richness. No information is available concerning the relationship of edaphic, physical, biological, and environmental variables to the resultant plant community composition following leafy spurge suppression.

Although rigorous experimental designs were used to monitor plant community changes at the primary study areas, it was also important to assess the success of flea beetle control of leafy spurge over the expanded area. Logistically it was not possible to assess all flea beetle release sites; therefore, using returned rancher survey questionnaires, a subset of sites within the Little Missouri River drainage including regions of Montana, North Dakota, South Dakota, and Wyoming were selected (Hodur et al. 2006). The objectives of this study were twofold. The first was to compare the change over time in leafy spurge stem density and foliar cover and to determine flea beetle suppression of leafy spurge. The second objective was to assess the plant community composition of affected sites and evaluate the relationship between the postrelease site plant community and selected site environmental variables throughout the Little Missouri River drainage basin.

\section{MATERIALS AND METHODS}

\section{Study Area}

The Little Missouri River drainage basin originates in northeastern Wyoming and eventually flows into the Missouri River in northwestern North Dakota. The climate is considered semiarid with an annual precipitation of approximately $250 \mathrm{~mm}$ in northeastern Wyoming to $380 \mathrm{~mm}$ in northwestern North Dakota (US Department of Agriculture, Natural Resources Conservation Service [USDA, NRCS] 2003). Approximately $70 \%$ of the annual precipitation occurs between April and September (USDA, NRCS 2003). Precipitation received in the growing season between 1998 and 2003 averaged $26 \mathrm{~cm}$, which is also the $30-y \mathrm{r}$ average for the region.
The flora in northeastern Wyoming is typical of the Black Hills region of South Dakota. Ponderosa pine (Pinus ponderosa Laws.) forests and woodlands are common plant communities comprised of common juniper (Juniperus communis L.), Oregon grape (Berberis repens Lindl.), needle-and-thread grass (Hesperostipa comata [Trin. \& Rupr.] Barkworth spp. comata), western wheatgrass (Pascopyrum smithii [Rydb.] A. Löve), porcupine grass (Hesperostipa spartea [Trin.] Barkworth), big bluestem (Andropogon gerardii Vitman), green needlegrass (Nassella viridula [Trin.] Barkworth), and Kentucky bluegrass (Poa pratensis L.). Grasslands in this area are generally located in small pockets within the ponderosa pine community (National Cooperative Soil Survey 1983). Soils found in this area include floodplain/terrace soils, which consist primarily of deep and nearly level loamy soils, and soils derived from sedimentary rock (e.g., siltstone, sandstone, and shale) that are deep to very deep and found on slopes ranging from $6 \%$ to $30 \%$. The Crook County soil survey (National Cooperative Soil Survey 1983) described most soils in the region as highly erosive with some susceptible to landslides.

As the Little Missouri River flows northeastward into southeastern Montana, South Dakota, and North Dakota, vegetation is typical of the northern mixed grass prairie. Plants in the region include western wheatgrass, blue grama (Bouteloua gracilis [Willd. ex Kunth] Lag. ex Griffiths), and green needlegrass (Barker and Whitman 1988). The soils are generally very deep, well drained, and moderately permeable. Slopes range from $0 \%$ to $30 \%$, with numerous sites along the Little Missouri River being deeply eroded and rough (National Cooperative Soil Survey 1975).

Flea beetles were collected and distributed to cooperators from TLS insectiaries in June and July 1998-1999. The beetles were distributed in cartons of either 3000 A. czwalinael lacertosa (black flea beetles) or 3000 A. nigiscutis (brown flea beetles) to cooperators with the recommendation to release one carton of each species of flea beetle at each release site. Surveys were mailed to 202 county weed boards and 468 landowner/ land managers in April 2002 (Hodur et al. 2006). Approximately 120 survey participants were located along the Little Missouri River drainage of Montana, North Dakota, South Dakota, and Wyoming. Of these, 43 landowners/land managers and county weed board agents were selected as potential partners for this study. Of the managers selected, a total of 292 flea beetle release sites, 204 in North Dakota, 36 in Montana, 27 in South Dakota, and 25 in Wyoming, were identified as potential future data collection sites.

\section{Landscape Level Assessment}

The survey data were restricted to include only sites occurring in the Little Missouri drainage basin and nearby areas. Selected data were again subsampled based on land owner response and willingness to allow field crews access to the site. When sites were not available in the Little Missouri River basin, sites close to those selected but not in the basin were substituted. A total of 29 sites outside the basin were included in the analyses.

Release site evaluations included visual estimation of leafy spurge foliar cover, stem density, and area of suppression (if applicable). Additionally, the presence or absence of shrub species and the number of trees within $10 \mathrm{~m}$ of the release site 
were evaluated as environmental variables used in canonical correspondence analysis. To determine flea beetle success in the Little Missouri River basin, pre-TLS leafy spurge foliar cover and stem density data were compared to cover and density data collected during this study. Pre-TLS leafy spurge cover and density data were collected by TLS cooperating scientists using the site assessment techniques as discussed in the next subsection before flea beetle release on anywhere from 50 to 200 sites, depending on the state. However, pre-TLS leafy spurge data were lacking for some areas including foliar cover for Wyoming and stem density for South Dakota and Wyoming.

Topoedaphic characteristics evaluated at each site used in canonical correspondence analysis were soil texture, site topography, topographic position, risk of spring flooding, soil drainage, and average annual precipitation. Cultural and management characteristics evaluated included previous year land use, current land use, and projected land use for each site.

Leafy spurge change following flea beetle release was determined by measuring the length and width of the area suppressed. Suppression was visually estimated based on a significant decrease in height and/or density of leafy spurge. The total area of leafy spurge suppression was estimated by using the formula

$$
\begin{aligned}
& \text { Area of Suppression }\left(\mathrm{m}^{2}\right) \\
& =\pi \frac{(\text { major axis }(\mathrm{m}))}{2} \frac{(\text { minor axis }(\mathrm{m}))}{2} .
\end{aligned}
$$

The total area suppressed was further categorized into 1$1000 \mathrm{~m}^{2}, 1000-5000 \mathrm{~m}^{2}, 5000-10000 \mathrm{~m}^{2}$, and greater than $10000 \mathrm{~m}^{2}$ to determine relative success of flea beetle establishment and average size of leafy spurge suppression on release sites in each state.

\section{Site Level Assessment}

A baseline perpendicular to the slope of each flea beetle release site was established through the center (actual release) point of each site to evaluate leafy spurge foliar cover. Subsequently, 10 26-m transects, five up and five down slope, were fixed at $36^{\circ}$ increments from the baseline center point. Random nonadjacent transects, two up and two down slope, were selected at each site for vegetative sampling. Leafy spurge foliar cover and stem density were estimated using $0.1 \mathrm{~m}^{2}$ Daubenmire quadrats (Daubenmire 1959) placed $2.5 \mathrm{~m}$ from the center on the randomly selected transects. Leafy spurge foliar cover values were averaged using the appropriate midpoints for Daubenmire cover classes.

Plant community composition of each release site was also evaluated. A $10-\mathrm{m}$ diameter circle centered on the release site was divided into four equal quadrants (northwest, northeast, southeast, and southwest). Vegetative composition was evaluated based on the visual percentage cover estimate of eight general plant categories within a $1-\mathrm{m}^{2}$ frame placed randomly within each quadrant. The eight vegetation categories used to evaluate release site plant composition were perennial native grasses, invasive exotic grasses, leafy spurge, native annual/ biennial forbs, native perennial forbs, invasive forbs, western snowberry, and other shrubs. The same field team estimated cover for each frame.

Native graminoid species at release sites that were combined into the "Perennial native grasses" class were based on the ecological site and the Historic Climax Plant Community for the release site (USDA, NRCS 2003). Species included in the "Invasive exotic grasses" were Kentucky bluegrass, smooth brome (Bromus inermis Leyss.), crested wheatgrass (Agropyron cristatum L.), cheatgrass (Bromus tectorum L.), and Japanese brome (Bromus japonicus Thunb. ex Murr.). Plant community structure was determined by averaging the four $1-\mathrm{m}^{2}$ frames for each plant species category within each release site.

\section{Statistical Analyses}

Leafy spurge foliar cover and stem density values were averaged across all release sites within each of the four states. Pre-TLS leafy spurge cover and stem density data, as a reference point, were averaged across all environments and conditions within each state. Though many pre- and post-TLS release sites within the four states may have been in proximity, this information could not be verified. Therefore, direct comparison of pre- and post-TLS leafy spurge foliar cover and density were not conducted.

Foliar cover of the eight release site vegetation categories and leafy spurge were compared using hierarchal agglomerative cluster analysis to characterize change in plant communities composition following flea beetle release (McCune and Grace 2002; PC-ORD, MjM Software Design 2002). A linear distance measure between clusters was calculated using a flexible beta linkage $(-0.25)$. The number of clusters chosen was determined by the indicator species method of Dufrene and Legendre (1997; as implemented in PC-ORD, MjM Software Design 2002). The indicator value of each plant species category was calculated according to cluster similarity to the various cluster definitions. The vegetation category indicator values were tested with a Monte Carlo simulation (1 000 runs) to see if community composition was due to something other than random chance (no community structure). The number of clusters chosen was based on the highest number of significant indicator species for a certain set of clusters and the lowest overall $P$-value for all the species in the set.

Canonical correspondence analysis (CCA) was used to evaluate the relationship between the release site plant community following flea beetle control of leafy spurge and site environmental variables (Ter Braak 1986; McCune and Grace 2002; PC-ORD, MjM Software Design 2002). Twenty environmental variables collected at each of the flea beetle release sites were used in the CCA (Table 1). Environmental variables contained both categorical and continuous variables and did not include leafy spurge-influenced variables in the model because of the skewing of the ordination results. Categorical variables were coded with dummy variables for use in CCA to facilitate analysis. The CCA model included biplot scaling and plant species category scores as a weighted mean of the site scores. A Monte Carlo test (1000 simulations) was conducted to determine if a linear relationship existed between flea beetle release site plant community composition (plant species categories) and the release site environmental variables. Site environmental variables with an $R^{2}$ of greater 
Table 1. Environmental variables included in the canonical correspondence analysis ordination.

\begin{tabular}{ll}
\hline \multicolumn{1}{c}{ Environmental variables } & Type \\
\hline Site topography (convex) & Categorical \\
Site topography (concave) & Categorical \\
Release site is xeric & Categorical \\
Release site is on a hill slope & Categorical \\
Release site is on bottomland or riparian area & Categorical \\
Release site is on a draw slope & Categorical \\
Risk of spring flooding & Categorical \\
Release site soils are well drained & Categorical \\
Release site is in a pasture setting & Categorical \\
Grazing occurs on the release site & Categorical \\
Trees present or absent on the release site & Categorical \\
Flea beetles present on the release site & Categorical \\
Release site on a sandy range site & Categorical \\
Release site on an overflow range site & Categorical \\
Release site on an upland range sites (silty, thin upland) & Categorical \\
Elevation of release sites (in 333 m increments) & Numerical \\
Amount of slope & Numerical \\
Aspect & Numerical \\
No. of trees within 10 m diameter of release site & Numerical \\
No. of trees surrounding release site within 0.45 ha & Numerical \\
\hline
\end{tabular}

than 0.2 with the ordination axes were depicted visually as vectors against the biplot graph of the site ordination scores.

\section{RESULTS}

\section{Landscape Level Assessment}

Leafy spurge foliar cover averaged over $50 \%$ pre-TLS and approximately $10 \%$ 4-5 yr after flea beetle establishment in the study areas of Montana, North Dakota, and South Dakota (Fig. 1). Additionally, leafy spurge foliar cover was less than $5 \%$ on approximately two-thirds of the flea beetle release sites and less than $25 \%$ on over $90 \%$ of the release sites. No pre-TLS leafy spurge foliar cover in Wyoming or stem density in South Dakota and Wyoming were available. On two-thirds of the

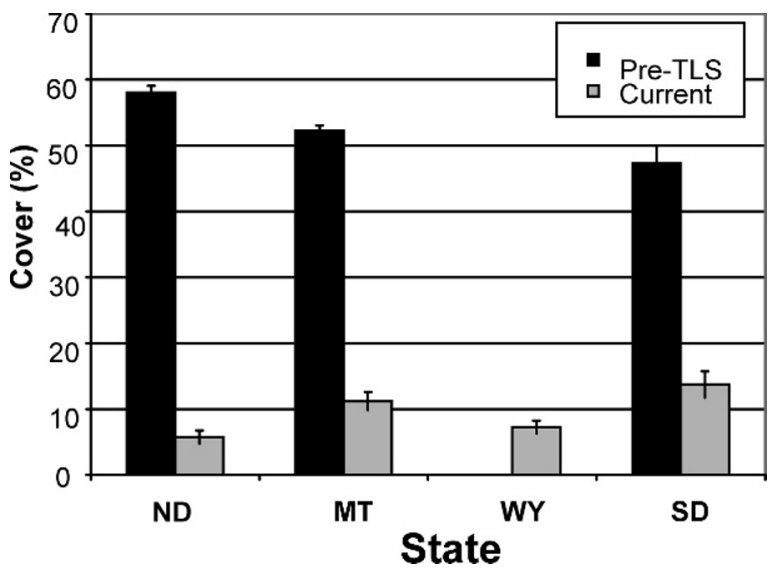

Figure 1. Leafy spurge foliar cover (\%), pre-TEAM Leafy Spurge (TLS) and current (2002-2003), by state within the Little Missouri River drainage basin.

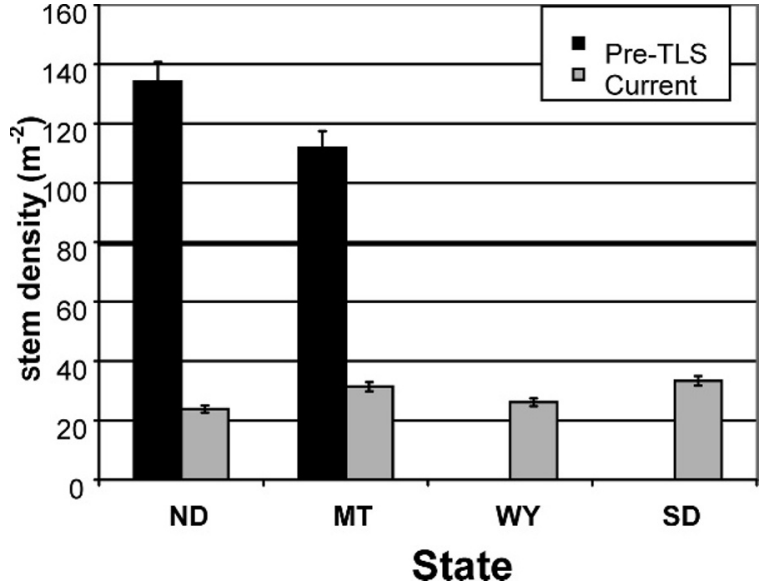

Figure 2. Leafy spurge stem density $\left(\right.$ stems $\cdot \mathrm{m}^{-2}$ ), pre-TEAM Leafy Spurge (TLS) and current, by state within the study area. Leafy spurge stem density greater than 80 stems $\cdot \mathrm{m}^{-2}$ has been reported to decrease cattle use (Lym and Kirby 1987).

study sites stem density was reduced from greater than 100 stems $\cdot \mathrm{m}^{-1}$ to less than 25 stems $\cdot \mathrm{m}^{-1}$ (Fig. 2). In Montana and North Dakota, leafy spurge stem density decreased from approximately $120 \mathrm{stems} \cdot \mathrm{m}^{-1}$ to $25 \mathrm{stems} \cdot \mathrm{m}^{-1}$ over $5 \mathrm{yr}$. Overall, leafy spurge foliar cover and stem density were reduced on $91 \%$ of the available release sites as determined by the presence or absence of leafy spurge.

Area of leafy spurge suppression, in the immediate area surrounding the release site, varied widely throughout the study region and ranged in size from approximately $5 \mathrm{~m}^{2}$ to over $35000 \mathrm{~m}^{2}$. Approximately $40 \%$ of the release sites had an area of suppression between 1-1 $000 \mathrm{~m}^{2}, 40 \%$ of the release sites had leafy spurge control of between $1000-5000 \mathrm{~m}^{2}, 5 \%$ had an area of suppression between $5000-10000 \mathrm{~m}^{2}$, and $5 \%$ of sites had an area of suppression greater than $10000 \mathrm{~m}^{2}$. Area of leafy spurge suppression averaged nearly $3200 \mathrm{~m}^{2}$ per flea beetle release in North Dakota, approximately $1700 \mathrm{~m}^{2}$ in northeastern Wyoming, $1220 \mathrm{~m}^{2}$ in South Dakota, and eastern Montana had the smallest average suppression area of $600 \mathrm{~m}^{2}$. Leafy spurge suppression was not evident on $9 \%$ (27) of the release sites. Of the 27 sites, 18 had soils that were either sandy loams or loamy sands.

\section{Site Level Assessment}

Plant community composition following leafy spurge suppression by flea beetles was dependent on the vegetation present before leafy spurge infestation and the topoedaphic characteristics of the site. The hierarchical agglomerative clustering analysis conducted in conjunction with the indicator species method found that six clusters were best at characterizing plant communities in the region following leafy spurge control (Table 2). Clusters 2 and 3 characterized most plant communities evaluated $(69 \%)$, although the two clusters differed in plant species composition. Cluster 2 was characterized by a higher cover of perennial native grasses with few invasive exotic grasses, and cluster 3 had a much higher coverage of invasive exotic grasses as well as fewer perennial native grasses and a small coverage of noxious plants other than leafy spurge. Cluster 4 represented $18 \%$ of the sites visited, and its composition had equal cover of perennial native grasses and 
Table 2. Mean canopy coverage of the species groups for each of the clusters found in the hierarchical agglomerative cluster analysis along with the percentage of sites found in each cluster.

\begin{tabular}{|c|c|c|c|c|c|c|c|c|}
\hline Cluster & $\begin{array}{l}\% \text { of } \\
\text { sites }\end{array}$ & $\begin{array}{c}\text { Perennial } \\
\text { native grasses }\end{array}$ & $\begin{array}{c}\text { Invasive exotic } \\
\text { grasses }\end{array}$ & $\begin{array}{l}\text { Native forbs, } \\
\text { annual or biennial }\end{array}$ & $\begin{array}{l}\text { Native forbs } \\
\text { perennial }\end{array}$ & $\begin{array}{c}\text { Other } \\
\text { noxious forbs }\end{array}$ & $\begin{array}{l}\text { Western } \\
\text { snowberry }\end{array}$ & $\begin{array}{l}\text { Other } \\
\text { shrubs }\end{array}$ \\
\hline 1 & 7 & 6.8 & 20.6 & 0.6 & 4.1 & 0.0 & 32.0 & 1.2 \\
\hline 2 & 33 & 33.2 & 7.3 & 1.2 & 4.5 & 0.0 & 3.3 & 2.2 \\
\hline 3 & 36 & 5.2 & 32.7 & 1.3 & 2.2 & 0.1 & 4.3 & 0.9 \\
\hline 4 & 18 & 15.9 & 15.9 & 1.7 & 3.2 & 0.0 & 0.2 & 1.5 \\
\hline 5 & 4 & 4.3 & 23.3 & 16.1 & 5.8 & 0.0 & 0.2 & 0.0 \\
\hline 6 & 3 & 5.5 & 7.5 & 0.3 & 1.3 & 0.0 & 0.0 & 12.8 \\
\hline
\end{tabular}

invasive exotic grasses. The remaining clusters characterized approximately $14 \%$ of sites and were comprised of high amounts of certain plant groups (e.g., western snowberry), annual or biennial native forbs, or other shrubs. Clusters 1, 2, and 6 were sites primarily composed of native plants (grasses and shrubs), while the plant species of the remaining sites were characterized by invasive exotic plants.

CCA analysis and Monte Carlo tests determined that a significant linear relationship in the plant community structure and the site environmental variables $(P$-value $=0.001)$ existed. The CCA analysis explained $22 \%$ of the total variance with the first axis explaining $12 \%$ and the second axis $7 \%$. The first and second axes explained much of the cumulative variance; therefore, these were the only axes used in the interpretation.

Several environmental variables were strongly correlated with axes 1 and $2\left(R^{2}>0.2\right.$; Fig. 3$)$. The environmental variables "risk of spring flooding" and "bottomland areas" were both positively and strongly correlated with axis 1 ; the variable "xeric moisture conditions" was negatively and strongly correlated with axis 1. This arrangement of the strongly correlated variables, where they are opposites, indicates that axis 1 is associated with a moisture gradient based on topography. "Overflow sites" and "draw slopes" were both positively and strongly correlated with axis 2 , which indicates that axis 2 was associated with a topographic gradient.

The species group "invasive exotic grasses" was positively associated with axis 1 and increased from left "xeric moisture conditions" to "risk of spring flooding" or "bottomland areas" on the right end of the axis (Fig. 4). Conversely, the species group "perennial native grasses" had higher cover at the left end of axis 1, which was associated with "xeric conditions" (Fig. 5). Western snowberry (Symphoricarpos occidentalis Hook.) was strongly correlated with axis 2 , indicating a greater occurrence of western snowberry on overflow sites and draw slopes (Fig. 6). There appears to be a strong correlation between plant species composition following leafy spurge suppression and topographic position of the release sites.

\section{DISCUSSION}

Release sites evaluated during this study indicate that introduced flea beetles are an effective method for managing leafy spurge under most conditions. We observed a reduction in leafy spurge stem density and foliar cover to levels below economic significance 4-5 yr after insects were released (Lym and Kirby 1987). The assessment of the relatively large Little Missouri
River drainage basin did provide evidence that introduced flea beetles can be established in most ecological conditions represented in the region. The release of flea beetles need not be restricted to a particular plant community type nor specific topoedaphic site, even if they previously did not establish in similar circumstances. Given the high cost of herbicides and the resistance of some managers to use alternative control measures (sheep and goats), flea beetles can provide effective, affordable, and sustainable management of leafy spurge on rangeland.

The results from this study were consistent with studies by Hansen (1993), Baker et al. (1996), Stromme et al. (1996), and Kirby et al. (2000), who also reported leafy spurge suppression by flea beetles at various sites in the Northern Great Plains. However, leafy spurge suppression was not evident on $9 \%$ (27) of the release sites. Of the 27 sites, 18 had soils that were either

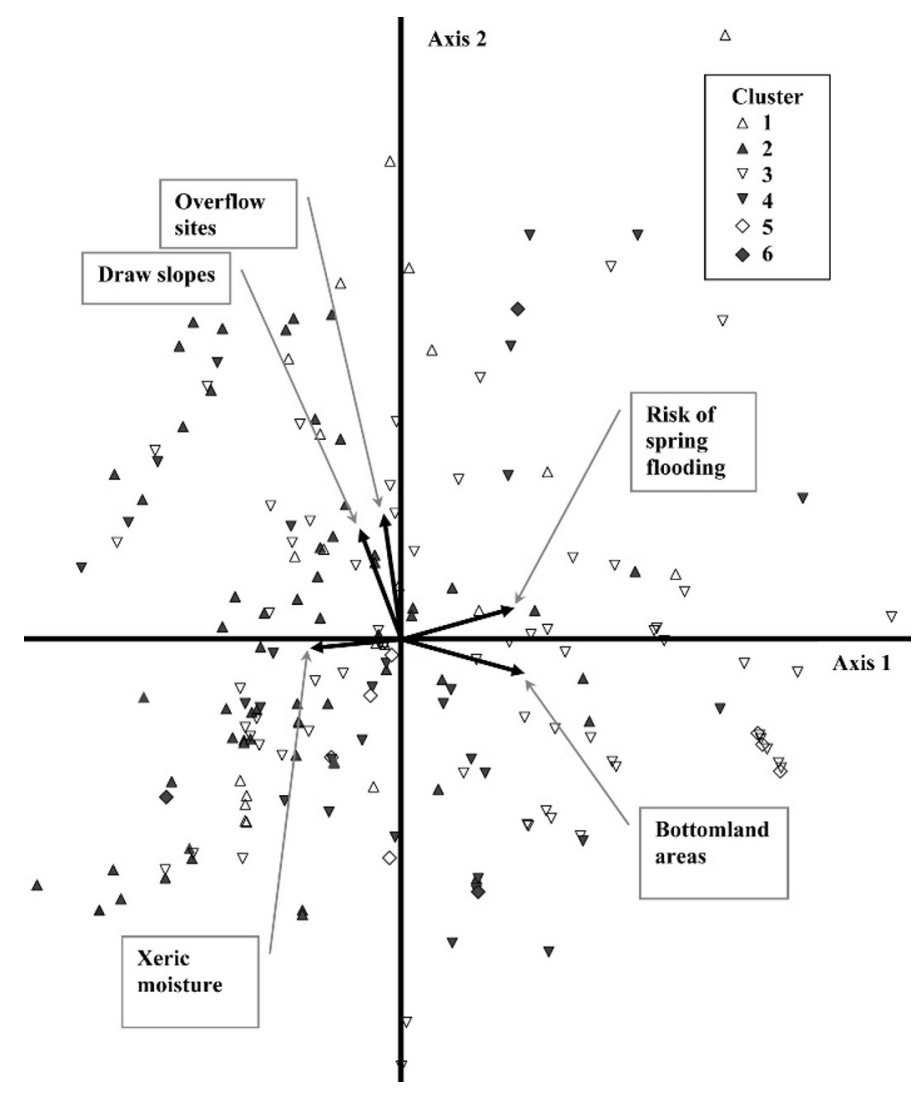

Figure 3. Biplot of plant community sites and vectors of site environmental variables with $R^{2}$ greater than 0.2 against the first and second ordination axes from the canonical correspondence analysis. Plant community sites are color coded according to their cluster grouping. 


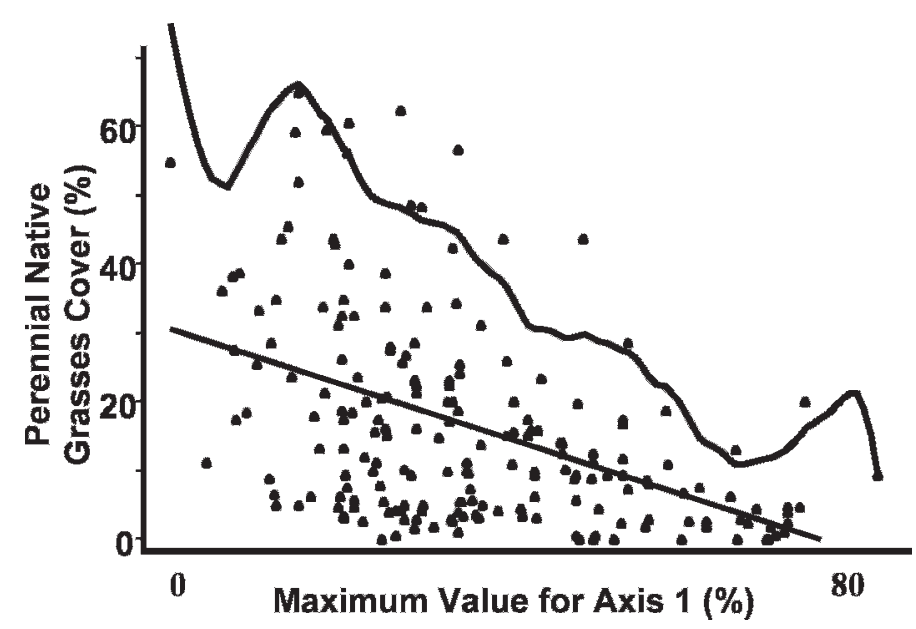

Figure 4. Correlation $(r=0.475)$ of invasive exotic grass species with axis 1 . Both regression line and envelope line are displayed. The envelope line is the approximate upper bound (two standard deviations) of the variable in relation to the ordination axis.

sandy loams or loamy sands, where flea beetle establishment may be poor (Lym 1998; Mundal and Carlson 1999; Kirby et al. 2000). No other environmental factors were consistently observed in this study that would account for the lack of leafy spurge suppression after flea beetle release.

Although no reference is available, we believe that frequent and prolonged flooding contributed to the lack of leafy spurge suppression at some sites. Early spring flooding could result in a significant number of flea beetle instars dying in the root before emerging as adults. However, a site's risk of spring flooding in this study did not consistently predict flea beetle success. Six sites with no suppression were located adjacent to a river in a flood plain that was prone to regular, persistent spring flooding. Five additional sites prone to flooding and located along lower-order stream channels that did not experience the same frequency or duration of flood events exhibited adequate leafy spurge suppression following flea beetle release. Additional research is needed to determine the effect of sandy soils, spring flooding, and other factors influencing over-winter flea beetle survival.

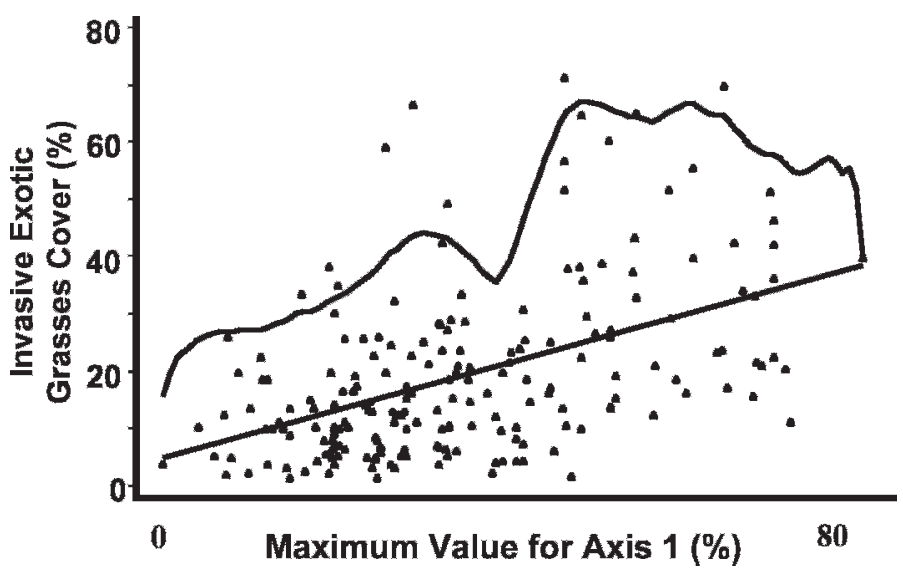

Figure 5. Correlation $(r=-0.47)$ of perennial native grass species with axis 1 . Both regression line and envelope line are displayed. The envelope line is the approximate upper bound (two standard deviations) of the variable in relation to the ordination axis.

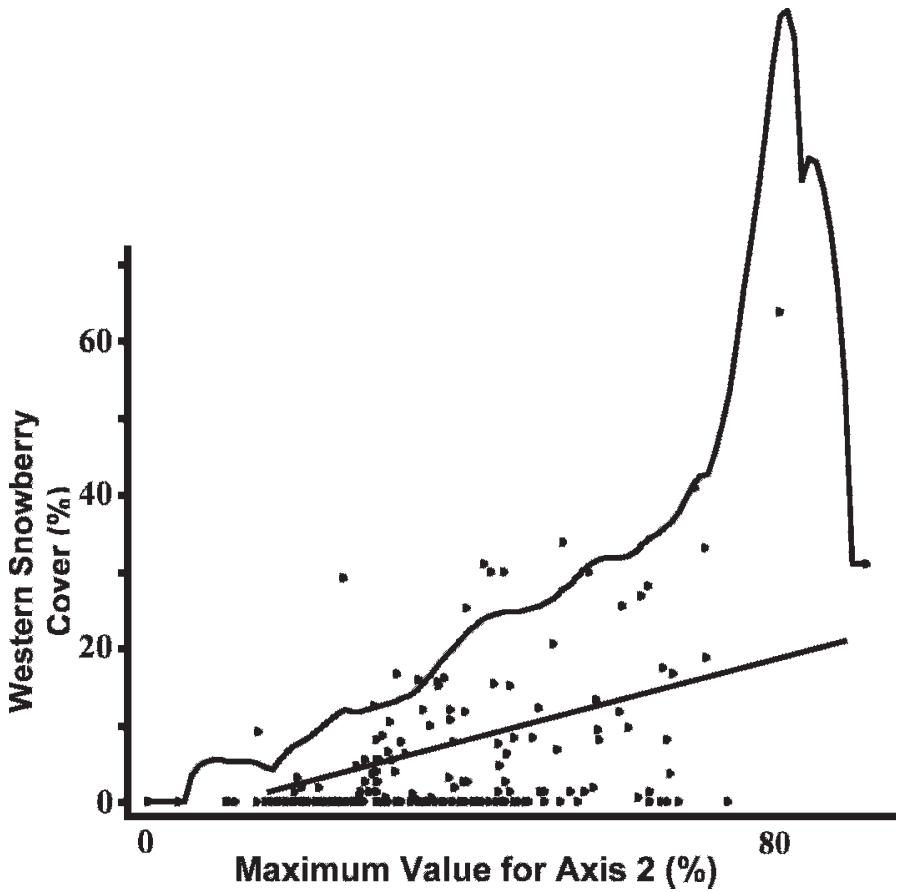

Figure 6. Correlation $(r=0.477)$ of western snowberry (S. occidentalis Hook.) with axis 2. Both regression line and envelope line are displayed. The envelope line is the approximate upper bound (two standard deviations) of the variable in relation to the ordination axis.

After leafy spurge suppression, $43 \%$ of the sites as identified in the clustering analysis were composed primarily of native plants (grasses and shrubs), and the plant species of the remaining sites were characterized by invasive exotic plants. The relatively short period of time following leafy spurge suppression did not produce an immediate shift from leafy spurge to other invasive exotic plants. A large percentage of the sites remained dominated by a small assemblage of native plants and the vigor of most sites was lower than non-leafy spurge-infested sites as also observed by Kirby et al. (2000).

The low amount of variability explained between the plant community data and the site environmental variables suggests that not all site environmental variables that affected the plant communities were measured in this study. Important environmental variables not measured that probably had a large influence on the plant communities were prior land use, length of time leafy spurge infested the area, and the seedbank resource for recolonization. Inclusion of these variables would likely improve the amount of variability explained by the site environmental factors using the CCA analysis.

Comparison of the resulting plant communities after leafy spurge suppression in this study with the "plant communities and state and transition models" developed for the ecological sites of the study area (USDA, NRCS 2003) suggests that these plant communities are similar in species composition to comparable ecological sites that are undisturbed (no fire and no grazing). These "undisturbed" plant communities tend to contain higher amounts of native perennial grasses in ecological sites that are more xeric, whereas more mesic sites have higher amounts of invasive exotic grasses. This trend follows the CCA analysis in that the more xeric the site, the higher the incidence of native perennial grasses, whereas the more mesic sites have a 
higher incidence of invasive exotic grasses. The relationship of sites in this study to "undisturbed" plant communities was not surprising given that the most common grazing herbivore in the Little Missouri River drainage are domestic cattle that avoid grazing in dense leafy spurge patches (Lym and Kirby 1987). Therefore, areas previously dominated by leafy spurge received very little grazing pressure. When or if these sites will approach the composition of typical, native mixed grass prairie in the future remains unknown.

\section{MANAGEMENT IMPLICATIONS}

Leafy spurge-infested areas doubled every decade in North Dakota until the 1990s primarily because leafy spurge has no evident natural enemies (USDA, Agricultural Research Service 2000). In the most recent decade, leafy spurge has not increased in area because of increased awareness and active control efforts such as biocontrol with Aphthona spp. flea beetles. This study found that 4-5 yr after Aphthona spp. flea beetle release, leafy spurge stem density and cover was suppressed at $91 \%$ of the sites evaluated within the Little Missouri River drainage basin. The resulting plant community after leafy spurge suppression resembled undisturbed communities (no grazing and no fire) that are characterized by an increased occurrence of native perennial grasses in xeric sites and more invasive exotic grasses such as Kentucky bluegrass in mesic areas. The management implications are 1) flea beetles are a viable option for leafy spurge suppression, and the continued release of beetles will hasten the process; 2) most sites will have some leafy spurge suppression from introduction of flea beetles; and 3) because the plant communities after leafy spurge suppression are characteristic of undisturbed plant communities, grazing to stimulate graminoid tillering or fall prescribed burning following flea beetle egg laying may be management options applied to hasten restoration of native plant communities.

\section{LITERATURE CITED}

Anderson, G. L., E. S. Delfosse, N. R. Spencer, C. W. Prosser, and R. D. Richard. 2003. Lessons in developing successful invasive weed control programs. Journal of Range Management 56:2-12.

BakeR, J. L., N. A. P. Webber, K. K. Johnson, and R. L. Lavigne. 1996. The behavior of Aphthona nigriscutis and the response of leafy spurge over a four year period in Fremont County Wyoming. In: R. G. Lym [ED.]. Proceedings of the 48th Annual Meeting; 11-14 March. Albuquerque, NM, USA: Western Society of Weed Science. p. 47-48.

Bangsund, D. A., and F. L. Leistritz. 1991. Economic impacts of leafy spurge on grazing lands in the Northern Great Plains. Fargo, ND, USA: North Dakota State University, Agriculture Economics Report 275-S. 85 p.

Barker, W. T., And W. C. Whitman. 1988. Vegetation of the northern Great Plains. Rangelands 10:266-272.

Butler, J. L., and D. R. Cogan. 2004. Leafy spurge effects on patterns of plant species richness. Journal of Range Management 57:305-311.

Butler, J. L., M. S. Parker, and J. T. Murphy. 2006. Efficacy of flea beetle control of leafy spurge in Montana and South Dakota. Rangeland Ecology and Management 59:453-461.

Dahlsten, D. L. 1986. Control of invaders. In: M. A. Mooney and J. A. Drake [eds.]. Ecology of biological invasions of North America and Hawaii. New York, NY, USA: Springer. p. 275-300.
Daubenmire, R. 1959. A canopy-coverage method of vegetational analysis. Northwest Science 33:43-64.

Dufrene, M., And P. Legendre. 1997. Species assemblages and indicator species: the need for a flexible asymmetrical approach. Ecological Monographs 61:53-73.

Dunn, P. H. 1979. The distribution of leafy spurge (Euphorbia esula) and other weedy Euphorbia spp. in the United States. Weed Science 27:509-516.

Gassmann, A., and D. Schroeder. 1995. The search for effective biological control agents in Europe: history and lessons from leafy spurge and cypress spurge. Biological Control 5:466-477.

Gassmann, A., D. Schroeder, E. Maw, and G. Sommer. 1996. Biology, ecology and host specificity of European Aphthona spp. used as biocontrol agents for leafy spurge, Euphorbia esula, in North America. Biological Control 6:105-113.

Hansen, R. 1993. Effects of Aphthona flea beetles and sheep grazing in leafy spurge stands. Proceedings of the Leafy Spurge Symposium; 26-28 July 1993; Silver Creek, CO, USA. p. 47-48.

Harris, P., P. H. Dunn, D. Schroeder, and R. Vonmoos. 1985. Biological control of leafy spurge in North America. In: A. K. Watson [ED.]. Monograph series of the Weed Science Society of America. Champaign, IL, USA: Weed Science Society of America. p. 79-92.

Hodur, N. M., F. L. Leistritz, and D. A. Bangsund. 2006. Biological control of leafy spurge: utilization and implementation. Rangeland Ecology and Management 59:445-452.

Kirby, D. R., R. B. Carlson, K. D. Krabbenhoft, D. Mundal, and M. M. Kirby. 2000. Biological control of leafy spurge with introduced flea beetles (Aphthona spp.). Journal of Range Management 53:305-308.

LYM, R. G. 1998. The biology and integrated management of leafy spurge (Euphorbia esula) on North Dakota rangeland. Weed Technology 12:367-373.

LYM, R. G., AND D. R. KIRBY. 1987. Cattle foraging behavior in leafy spurge infested rangeland. Weed Technology 1:314-318.

Lym, R. G., AND J. A. Nelson. 2000. Biological control of leafy spurge with Aphthona spp. along railroad right-of-ways. Weed Technology 14:642-646.

McCune, B., And J. B. Grace. 2002. Analysis of ecological communities. Gleneden Beach, OR, USA: MjM Software Design. 300 p.

Mundal, D. A., and R. B. Carlson. 1999. Aphthona flea beetle establishment determined by soil composition and root growth pattern. In: Proceedings of the Leafy Spurge Symposium; 9 June 1999; Medora, ND, USA. 9 p.

National Cooperative Soll Survey. 1975. Soil survey of Bowman County, ND. Bowman, ND, USA: United States Department of Agriculture. 245 p.

National Cooperative Soll Survey. 1983. Soil survey of Crook County, WY. Laramie, WY, USA: United States Department of Agriculture. 182 p.

North Dakota Department of Agriculture. 2001. Annual survey of state listed noxious weeds. Bismarck, ND, USA: North Dakota Department of Agriculture. 2 p.

PIPER, G. L. 2004. Integrated weed management and biological control. In: E. M. Coombs, J. K. Clark, G. L. Piper, and A. F. Confroncesco, Jr. [EDs.]. Biological control of invasive plants in the United States. Corvallis, OR, USA: Oregon State Press. p. 114-121.

Quimbey, W. L., JR., Bruchart, C. J. Deloach, L. Knutson, and M. H. Ralphs. 1991. Biological control of rangeland weeds. In: L. James, J. O. Evans, M. H. Ralphs, and R. D. Child [EDS.]. Noxious range weeds. Boulder, CO, USA: Westview Press. p. 85-102.

Quimby, P. C., JR., And L. Wendel. 1997. The ecological area-wide management (TEAM)-leafy spurge. In: Executive summary wide area funding proposal. Sidney, MT, USA: USDA, ARS. $51 \mathrm{p}$.

Stromme, K., D. E. Cole, A. S. McClay, C. J. Richardson, and J. De Valois. 1996. Biocontrol of leafy spurge with Aphthona nigriscutis in Alberta "The Beverly Bridge Site." In: Proceedings of the Leafy Spurge Symposium; 13-15 August 1996; Brandon, Manitoba, Canada. p. 26-27.

Ter BraAk, C. J. F. 1986. Canonical correspondence analysis: a new eigenvector technique for multivariate direct gradient analysis. Ecology 67:1167-1179.

uSDA, Agricultural Research Service. 2000. Biological control of leafy spurge (second printing). Available at: http://www.team.ars.usda.gov/. Accessed 15 June 2006.

[USDA, nRCS] US Department of Agriculture, Natural Resources Conservation SERvicE. 2003. Electronic field office technical guide (eFOTG). Available at: http://www.nrcs.usda.gov/technical/efotg. Accessed 15 March 2004. 